\title{
Inherited Photoreceptor Degeneration Causes the Death of Melanopsin-Positive Retinal Ganglion Cells and Increases Their Coexpression of Brn3a
}

\author{
Diego García-Ayuso, ${ }^{1}$ Johnny Di Pierdomenico, ${ }^{1}$ Gema Esquiva, ${ }^{2}$ Francisco Manuel \\ Nadal-Nicolás, ${ }^{1}$ Isabel Pinilla, ${ }^{3}$ Nicolás Cuenca, ${ }^{2}$ Manuel Vidal-Sanz, ${ }^{1}$ Marta Agudo-Barriuso, ${ }^{1}$ \\ and María P. Villegas-Pérez ${ }^{1}$
}

${ }^{1}$ Instituto Murciano de Investigación Biosanitaria Hospital Virgen de la Arrixaca (IMIB-Virgen de la Arrixaca), and Departamento de
Oftalmología, Facultad de Medicina, Universidad de Murcia, Murcia, Spain
${ }^{2}$ Departamento de Fisiología, Genética y Microbiología, Universidad de Alicante, San Vicente del Raspeig, Alicante, Spain
${ }^{3}$ Servicio de Oftalmología, Hospital Clínico Universitario Lozano Blesa, Zaragoza, Spain

Correspondence: María P. VillegasPérez, Laboratorio de Oftalmología Experimental, Facultad de Medicina, Universidad de Murcia, Campus de Ciencias de la Salud, Carretera Buenavista s/n, 30120 El Palmar, Murcia, Spain;

mpville@um.es.

DG-A and JDP are joint first authors.

Submitted: March 5, 2015

Accepted: May 25, 2015

Citation: García-Ayuso D, Di Pierdomenico J, Esquiva G, et al. Inherited photoreceptor degeneration causes the death of melanopsin-positive retinal ganglion cells and increases their coexpression of Brn3a. Invest Ophthalmol Vis Sci. 2015;56:4592-4604. DOI:10.1167/iovs.15-16808
Purpose. To study the population of intrinsically photosensitive retinal ganglion cells (melanopsin-expressing RGCs, $\mathrm{m}^{+} \mathrm{RGCs}$ ) in $\mathrm{P} 23 \mathrm{H}-1$ rats, a rat model of inherited photoreceptor degeneration.

Methods. At postnatal (P) times P30, P365, and P540, retinas from P23H dystrophic rats (line 1, rapid degeneration; and line 3, slow degeneration) and Sprague Dawley (SD) rats (control) were dissected as whole-mounts and immunodetected for melanopsin and/or Brn3a. The dendritic arborization of $\mathrm{m}^{+} \mathrm{RGCs}$ and the numbers of $\mathrm{Brn} 3 \mathrm{a}^{+} \mathrm{RGCs}$ and $\mathrm{m}^{+} \mathrm{RGCs}$ were quantified and their retinal distribution and coexpression analyzed.

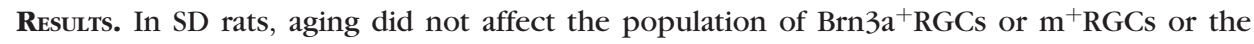
percentage that showed coexpression (0.27\%). Young $\mathrm{P} 23 \mathrm{H}-1$ rats had a significantly lower number of $\mathrm{Brn}_{3} \mathrm{a}^{+} \mathrm{RGCs}$ and showed a further decline with age. The population of $\mathrm{m}^{+} \mathrm{RGCs}$ in young $\mathrm{P} 23 \mathrm{H}-1$ rats was similar to that found in SD rats and decreased by $22.6 \%$ and $28.2 \%$ at P365 and P540, respectively, similarly to the decrease of the Brn3a+ RGCs. At these ages the $\mathrm{m}^{+} \mathrm{RGCs}$ showed a decrease of their dendritic arborization parameters, which was similar in both the $\mathrm{P} 23 \mathrm{H}-1$ and $\mathrm{P} 23 \mathrm{H}-3$ lines. The percentage of coexpression of Brn 3 a was, however, already significantly higher at P30 (3.31\%) and increased significantly with age (10.65\% at P540).

Conclusions. Inherited photoreceptor degeneration was followed by secondary loss of Brn $3 \mathrm{a}^{+} \mathrm{RGCs}$ and $\mathrm{m}^{+} \mathrm{RGCs}$. Surviving $\mathrm{m}^{+} \mathrm{RGCs}$ showed decreased dendritic arborization parameters and increased coexpression of Brn3a and melanopsin, phenotypic and molecular changes that may represent an effort to resist degeneration and/or preferential survival of $\mathrm{m}^{+} \mathrm{RGCs}$ capable of synthesizing Brn3a.

Keywords: $\mathrm{P} 23 \mathrm{H}$, retinitis pigmentosa, melanopsin, Brn3a, automated quantification, intrinsically photosensitive, photoreceptor degeneration, intrinsically photosensitive RGCs

\begin{abstract}
$T$ raditionally, rod and cones have been thought to be the only 1 cells that respond to light in the retina. However, there is a subtype of specialized retinal ganglion cells (RGCs) that expresses the photopigment melanopsin and thus, responds to light. These cells are named intrinsically photosensitive retinal ganglion cells (ipRGCs). ${ }^{1-4}$ Previous works ${ }^{1,5-12}$ have shown the important role of these cells for non-image forming visual functions such as the regulation of circadian rhythms or the pupillary light reflex. Moreover, it has been recently suggested that ipRGCs may be involved in image formation, ${ }^{13-16}$ even independently of conventional photoreception. ${ }^{17,18}$ Recent work has suggested that $\mathrm{m}^{+} \mathrm{RGCs}$ are more resistant than the rest of the RGC population to a number of retinal injuries, ${ }^{19}$ including axotomy, ${ }^{20,21}$ NMDA-mediated excitotoxicity, ${ }^{22}$ and mitochondrial optic neuropathies. ${ }^{23}$ There is also evidence indicating that in human glaucoma ${ }^{24-27}$ and ocular hypertension models ${ }^{28-30}$ ipRGCs are diminished, but
\end{abstract}

whether $\mathrm{m}^{+} \mathrm{RGCs}$ are also more resistant to ocular hypertensioninduced retinal degeneration is not clear. ${ }^{31-33}$

There are many animal and human diseases that proceed with photoreceptor degeneration. Retinitis pigmentosa (RP) is the commonest form in humans, representing an important cause of irreversible blindness. Retinitis pigmentosa is caused by mutations affecting rod proteins (e.g., rhodopsin) and therefore, it first causes the death of rods, ${ }^{34,35}$ but later there is a progressive loss of both rods and cones. ${ }^{35-38}$ With time, most layers of the retina are affected and most patients show optic disc pallor, which has been documented to be the result of RGC loss. ${ }^{39-46}$ In rodents, we have documented RGC loss both in inherited and induced photoreceptor degenerations and we have shown that this loss is at least in part due to RGC axonal compression by the normal retinal vessels that undergo displacement during retinal degeneration. ${ }^{12,47-53}$ It is now recognized that the diseases that proceed with photoreceptor 
degeneration may cause, with time, affectation of the inner retina and RGC degeneration. ${ }^{41-44,54-56}$ Several studies have shown disruption of the circadian rhythms both in animals ${ }^{56-58}$ and in humans ${ }^{59-61}$ with retinal degenerations. Because circadian rhythms are regulated through ipRGC circuitry and not traditional rod/cone visual pathways, these studies suggest that these cells could be affected in these diseases. The studies that have addressed this problem have given, however, conflicting results: while some studies have found loss of ipRGCs in animals with inherited photoreceptor degeneration, ${ }^{12,62,63}$ others have failed to show this result. ${ }^{64}$ Within the different animals models of retinal degeneration, we have recently characterized in detail the degenerative events that take place in the $\mathrm{P} 23 \mathrm{H}-1$ rat retina. ${ }^{51,65}$ The $\mathrm{P} 23 \mathrm{H}$ transgenic rat carries an autosomal dominant mutation in the rhodopsin gene that is found in $12 \%$ of the autosomal dominant RP cases in North America ${ }^{66,67}$ and thus, it is widely used to study RP.

We have documented previously that Brn3a is a good marker for the rodent RGC population ${ }^{68-73}$ because it does not require any surgical manipulations and is a strong nuclear marker. In the rat, this antibody labels $96 \%$ of the RGC population. ${ }^{68-70,72}$ We have also documented the number, spatial distribution, and Brn3a expression of ipRGCs in the normal rat retina. ${ }^{68-70}$ We have demonstrated that approximately $90 \%$ of these cells project to the superior colliculi ${ }^{68,70}$ but that only a very small proportion (0.20\%) express Brn3a. ${ }^{68-70}$ Brn3a thus labels most RGCs but not most ipRGCs. ${ }^{68-70}$ We have considered this apparent flaw of the Brn3a labeling as an advantage and used double immunodetection with Brn3a and melanopsin to study in parallel the degeneration of these two RGC subpopulations: the general RGC population and the ipRGC subtype. .2,32,33,68-70,73 $^{-10}$

In this study, using double immunodetection of Brn3a and melanopsin and our recently developed methods to quantify and map topographically, ${ }^{51-53,68-70,72-74}$ we document, for the first time, the short- and long-term effect of photoreceptor loss on the ipRGC population of the $\mathrm{P} 23 \mathrm{H}-1$ rat retina and the changes in Brn3a expression by these cells. Finally, we analyzed the changes in several dendritic parameters of ipRGCs in the $\mathrm{P} 23 \mathrm{H}-1$ and $\mathrm{P} 23 \mathrm{H}-3$ lines to assess whether extension of the outer retinal degeneration, slower in $\mathrm{P} 23 \mathrm{H}-3$, affects the dendritic status of the surviving ipRGCs differently.

\section{Materials ANd Methods}

For this study, $\mathrm{P} 23 \mathrm{H}$ transgenic rats and Sprague Dawley (SD) rats were used. The $\mathrm{P} 23 \mathrm{H}$ rats were produced by LaVail and colleagues (Steinberg RH, et al. IOVS 1996;37:ARVO Abstract 3190) using gene constructs with a rhodopsin mutation (single amino acid substitution at codon 23). The three lines of homozygous $\mathrm{P} 23 \mathrm{H}$ rats show different rates of photoreceptor degeneration: line 1 shows the fastest degeneration rate, followed by line 3 and line 2 , in this order (provided in the public domain by UCSF School of Medicine, San Francisco, CA, USA; http://www.ucsfeye.net/mlavailRDratmodels.shtml ${ }^{51,62,75}$ ). The different rates of retinal degeneration in the three $\mathrm{P} 23 \mathrm{H}$ rat lines are presumably due to a position effect from different transgene insertion sites in the rat genome ${ }^{76}$ (Steinberg RH, et al. IOVS 1996;37:ARVO Abstract 3190). In this context, at approximately postnatal (P) age P120, only one photoreceptor row remains in line $1,{ }^{51,77}$ whereas one to two rows of photoreceptor cell bodies are found in line 3 of $\mathrm{P} 23 \mathrm{H}$ rats at this age. ${ }^{78}$ The wildtype control for these transgenic animals is the albino SD rats.

\section{Animal Handling}

A total of 51 animals were used: $\mathrm{P} 23 \mathrm{H}-1$ rats of three different postnatal ages: P30 $(n=8), \mathrm{P} 180(n=8)$, and P540 $(n=7)$;
P23H-3 rats of two different ages: $\mathrm{P} 365(n=7)$ and $\mathrm{P} 540(n=$ $7)$; and age-matched SD rats: $\mathrm{P} 30(n=6), \mathrm{P} 365(n=2)$, and $\mathrm{P} 540(n=6)$. Transgenic homozygous $\mathrm{P} 23 \mathrm{H}-1$ and $\mathrm{P} 23 \mathrm{H}-3$ animals were obtained from LaVail and colleagues (UCSF School of Medicine; http:// www.ucsfeye.net/ mlavailRDratmodels.shtml) and were bred at the University of Murcia (P23H-1) or the University of Alicante (P23H-3); SD animals were obtained from the breeding colony of the University of Murcia, Spain. Rats were housed in temperature and light controlled rooms with a 12-hour light/dark cycle (light from $8 \mathrm{AM}$ to $8 \mathrm{PM}$ ) and with food and water ad libitum. Light intensity within the cages ranged from 5 to 30 lux (scotopic to mesopic conditions). Animal manipulations were carried out by following the Spanish and European Union regulations for the use of animals in research (Council Directive 86/609/EEC) and the ARVO Statement for the Use of Animals in Ophthalmic and Vision Research. Adequate measures were taken to minimize pain or discomfort.

\section{Tissue Processing}

All animals were processed between 10:00 AM and 12:00 AM to avoid the diurnal fluctuations in melanopsin expression. ${ }^{79,80}$ Rats were given a lethal dose of sodium pentobarbital (Dolethal Vetoquinol, S.A., Lure, France) and perfused transcardially through the ascending aorta first with saline and then with $4 \%$ paraformaldehyde in $0.1 \mathrm{M}$ phosphate buffer $(\mathrm{pH} 7.4)$. The eyes were then enucleated and the retinas were dissected as whole-mounts by making four radial cuts in the superior, inferior, nasal, and temporal retinal quadrants. Retinal orientation was maintained by making the deepest radial cut in the superior retina. ${ }^{73,81}$ The retinas were postfixed flat on a filter paper in $4 \%$ paraformaldehyde for 1 hour, washed in phosphate-buffered saline (PBS), and subjected to immunohistofluorescence.

\section{Immunohistofluorescence}

Retinas were washed and permeated as previously described. ${ }^{51-53,65,68-70,73,81}$ Whole-mounted retinas were incubated overnight at $4{ }^{\circ} \mathrm{C}$ with a mixture of both primary antibodies diluted in blocking buffer (PBS containing 2\% Triton $\mathrm{X}-100$ and 5\% normal donkey serum (Jackson ImmunoResearch, Inc., Cambridge, UK).

Secondary detection was performed by incubating the retinas for 1 hour at room temperature with a mixture of both secondary antibodies diluted in PBS-2\% Triton X-100. Finally, the retinas were washed in PBS and mounted on subbed slides vitreal side up, and covered with antifading mounting media (Vectashield Mounting Medium; Vector, Atom, Alicante, Spain).

\section{Antibodies and Dilutions}

Primary Antibodies. The total RGC population was detected by using goat anti-Brn3a (1:500, C-20; Santa Cruz Biotechnologies, Heidelberg, Germany). ${ }^{69,70,72}$ The ipRGCs were detected by using the rabbit anti-melanopsin PAI-780 (1:500; Thermo Scientific, Madrid, Spain) ${ }^{68,70}$ that detects the $\mathrm{NH}_{2}$ terminal of the melanopsin protein and thus both melanopsin isoforms (short and long ${ }^{68,69,82}$ ). Melanopsin immunodetection identifies the M1, M2, and M3 ipRGC subtypes, because the M4 and M5 subtypes are not stained with anti-melanopsin antibodies. ${ }^{13}$ We will refer to the population of ipRGCs detected with this antibody as $\mathrm{m}^{+}$RGCs.

Secondary Antibodies. Melanopsin was identified by using donkey anti-rabbit Alexa-488 (green fluorescence), while Brn3a was identified in the same retinas by using donkey anti- 
goat Alexa-594 (red fluorescence; Molecular Probes, Invitrogen, Barcelona, Spain), all diluted 1:500.

\section{Immunoperoxidase Labeling and Morphologic Analysis}

The dendritic morphology and stratification patterns of 10 $\mathrm{m}^{+}$RGCs of each type (M1, M1d, M2, and M3) per strain and age ( $n=40$ cells/strain and age) were manually drawn and digitized from whole-mounted rat retinas stained with the same rabbit anti-melanopsin antibody and with an $\mathrm{ABC}$ complex immunoperoxidase method. ${ }^{62}$ Morphologic differences in the dendritic parameters between strains and ages were analyzed by using a Bonfire analysis following previously described methods. 83

\section{Retinal Image Analysis}

Retinal whole mounts were examined and photographed by following standard procedures in our laboratory, ${ }^{51-53,68,69,72,81,84}$ using an epifluorescence microscope (Axioscop 2 Plus; Zeiss Mikroskopie, Jena, Germany) equipped with various filters, a digital high-resolution camera (ProgResTM C10; Jenoptik, Jena, Germany), and a computer-driven motorized stage (Pro-ScanTM H128 Series; Prior Scientific Instruments, Cambridge, UK) controlled by IPP (IPP 5.1 for Windows; Media Cybernetics, Silver Spring, MD, USA) with a microscope controller module (Scope-Pro 5.0 for Windows; Media Cybernetics). To make reconstructions of retinal wholemounts, retinal multiframe acquisitions were taken in a raster scan pattern as previously described in detail. $51-53,68,69,72,81,84$

\section{Quantification of Brn3a $\mathbf{a}^{+} \mathrm{RGCs}$}

To count $\mathrm{Brn}_{3} \mathrm{a}^{+} \mathrm{RGCs}$, the individual images taken in each retina were processed by a specific cell counting subroutine developed by our group. Briefly, we used the IPP macro language to apply different filters and transformations to each frame in order to clarify cell limits and separate individual cells for automatic cell counting, following procedures that have been previously reported in detail. ${ }^{51-53,68,69,72,84}$

\section{Quantification and Distribution of the Total Population of ipRGCs}

In a first step, $\mathrm{m}^{+} \mathrm{RGCs}$ were dotted manually in the retinal photomontage in a blinded masked fashion. Next, the images were analyzed by using a specific subroutine previously developed by our group. ${ }^{68,70}$ Finally, the obtained data (numbers of $\mathrm{m}+\mathrm{RGCs}$ and coordinates of each $\mathrm{m}^{+} \mathrm{RGC}$ in relation to the optic disc) were exported to a spreadsheet (Office Excel 2000; Microsoft Corp., Redmond, WA, USA) for further analysis.

Because of the low density of $\mathrm{m}^{+} \mathrm{RGCs}$, the k-nearest neighbor algorithm was chosen to study their distribution. For this purpose, we used a Java (Oracle Corporation, Redwood Shores, CA, USA) application previously developed by our group. ${ }^{68}$ Briefly, we chose a radius of study $(0.22 \mathrm{~mm})$; imported the spreadsheet obtained with the counting routine; and counted the $\mathrm{m}+\mathrm{RGCs}$ closer than the fixed radius, for each cell. Finally, every $\mathrm{m}^{+} \mathrm{RGC}$ was plotted in the outlined retina and colored by using a color scale representing the number of neighbors, using SigmaPlot (SigmaPlot 9.0 for Windows; Systat Software, Inc., Richmond, CA, USA). Normalized data from three retinas at each period analyzed were used to study ipRGC distribution: the data obtained after the spatial analysis allowed the extraction of the number of ipRGCs at a given distance from the optic disc in each retinal quadrant. All plots were performed with SigmaPlot as previously described. ${ }^{68,70,73}$

\section{Coexpression of Brn3a and Melanopsin}

In 20 standard areas of each retina (five areas per quadrant at five equidistant distances between the optic disc and the retinal periphery), photomicrographs were taken by using different fluorescence filters. In the photomicrographs, the number of RGCs that were melanopsin ${ }^{+}, \mathrm{Brn}_{3} \mathrm{a}^{+}$, or both, were manually identified and counted, and the colocalization of both markers was analyzed, with $100 \%$ representing the total number of $\mathrm{m}+\mathrm{RGCs}$ counted.

\section{RGC Isodensity Maps}

Brn $3 \mathrm{a}^{+}$RGCs isodensity maps were constructed for each retina to study the spatial distribution of these cells, by using the specific subroutine developed in IPP macro language by our group. ${ }^{33,51-53,69,70,84}$ These densities were represented as filled contour plots with SigmaPlot.

\section{Statistics}

Statistical analysis was done by using SigmaStat 3.1 for Windows (SigmaStat for Windows TM version 3.11; Systat Software, Inc.) or SPSS (SPSS 18.0 software; IBM, Armonk, NY, USA). For retinal populations, the ANOVA test was used when comparing more than two groups and the Mann-Whitney or the $t$-test when comparing two groups only. For morphologic analysis, a MANOVA (Multivariate Analysis of Variance) was used to evaluate differences between SD and $\mathrm{P} 23 \mathrm{H}$ rats. When a level of significance $\leq 0.05$ was found, post hoc pairwise comparisons using Bonferroni's test were performed. Differences were considered significant when $P<0.05$.

\section{Results}

\section{Total Population of Brn3a $\mathbf{a}^{+}$RGCs in the Aging P23H- 1 Rat}

At $\mathrm{P} 30$, the total number of $\mathrm{Brn} 3 \mathrm{a}^{+} \mathrm{RGCs}$ was significantly lower in the $\mathrm{P} 23 \mathrm{H}-1$ strain than in SD rats $(P<0.001$; MannWhitney test; Table 1) and represented $93.7 \%$ of the total numbers found in SD rats (Fig. 1A), in accordance with previously published data. ${ }^{51}$ In SD rats, age did not affect the total number of $\mathrm{Brn} 3 \mathrm{a}^{+} \mathrm{RGCs}$, as their population was similar from P30 to P540 (Table 1) and similar to that found in previous studies in control animals. ${ }^{51,81}$ In the $\mathrm{P} 23 \mathrm{H}-1$ rats, however, the population of Brn $3 \mathrm{a}^{+} \mathrm{RGCs}$ decreased with time and this decrease was significantly different between each survival interval (Fig. 1A; Table 1). These findings are in accordance with our previously published data in which we have documented that up to P365 there is a loss of $14 \%$ of Brn3a $\mathrm{a}^{+} \mathrm{RGCs}$ in the $\mathrm{P} 23 \mathrm{H}-1$ strain, ${ }^{51}$ and here we showed that there was further loss of $16.4 \%$ between 12 and 18 months of age (Fig. 1A). Also, as observed in Figure 2, the loss of Brn $3 \mathrm{a}^{+} \mathrm{RGCs}$ in the $\mathrm{P} 23 \mathrm{H}-1$ rat was diffuse and affected the whole retina.

\section{Melanopsin-Positive RGCs in the Aging P23H-1 Rat}

In $\mathrm{SD}$ rats, the mean total number of $\mathrm{m}^{+} \mathrm{RGCs}$ per retina was $2095 \pm 83$ and $2098 \pm 132$ at $\mathrm{P} 30$ and P540, respectively (mean $\pm \mathrm{SD}$; Table 1 ). These numbers were similar to those found in previous studies in SD and PVG (Piebald-Viral-Glaxo) control animals, ${ }^{68,70}$ indicating that in normal, nontransgenic rats, the population of $\mathrm{m}^{+} \mathrm{RGCs}$ does not decrease with age. These numbers were also not significantly different from the numbers of $\mathrm{m}^{+} \mathrm{RGCs}$ found in 1-month-old P23H-1 rats $(2125 \pm$ 263; Table 1). Thus, contrary to what happens with 


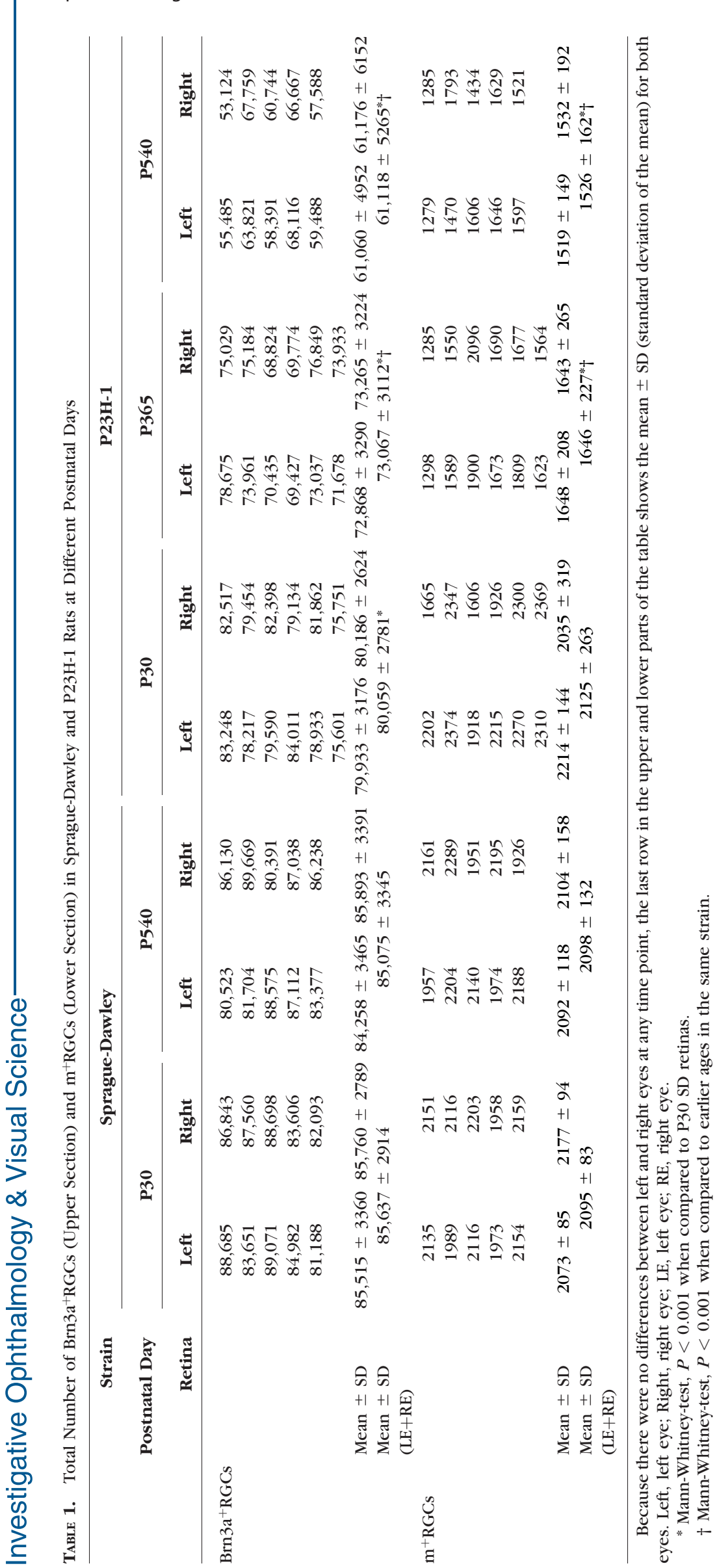



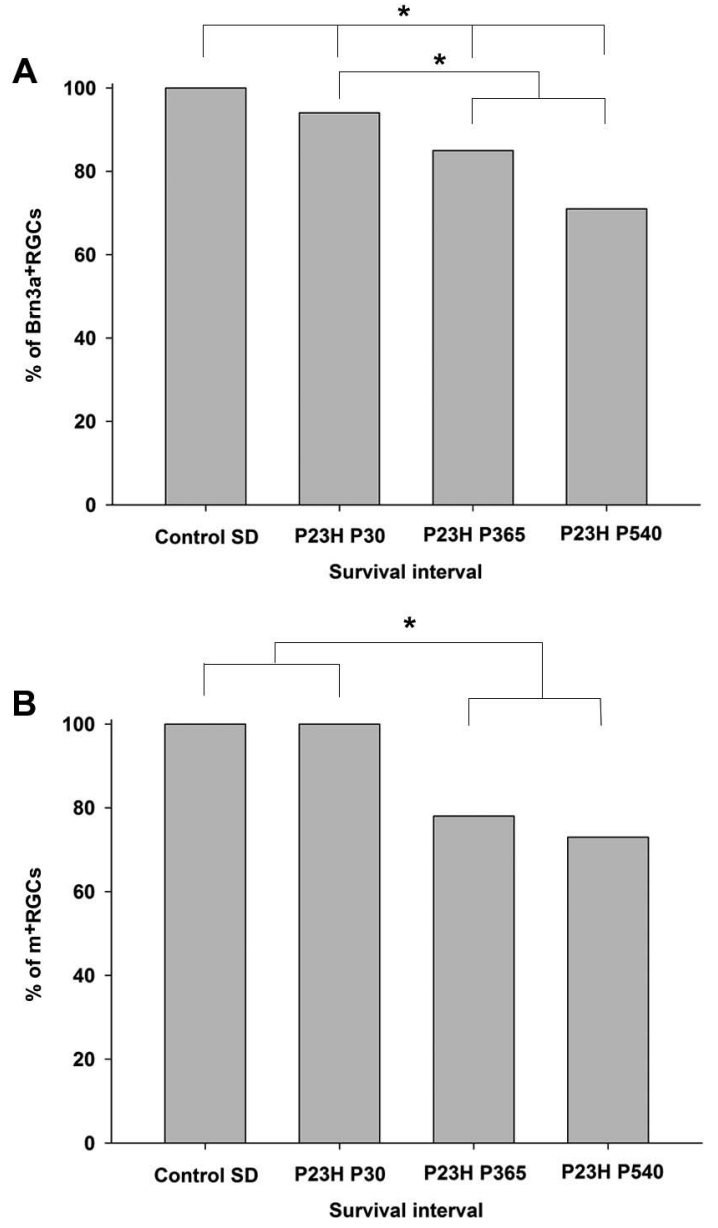

Figure 1. Loss of Brn $3 a^{+}$RGCs and of $m^{+}$RGCs in the P23H-1 rat. Percentages of Brn3 $\mathrm{a}^{+} \mathrm{RGCs}(\mathbf{A})$ and $\mathrm{m}^{+} \mathrm{RGCs}(\mathbf{B})$ in control SpragueDawley (control, SD) and in $\mathrm{P} 23 \mathrm{H}-1$ rats $(\mathrm{P} 23 \mathrm{H})$ at different postnatal times. These percentages were calculated by considering as $100 \%$ the number of cells in P30 SD rats. * indicate significant diferences.

Brn3a $\mathrm{a}^{+} \mathrm{RGCs}$, the population of $\mathrm{m}^{+} \mathrm{RGCs}$ in 1-month-old P23H-1 rats was not smaller than the population found in SD rats. In the transgenic rats, however, there was a significant decrease in the population of $\mathrm{m}^{+}$RGCs between $\mathrm{P} 30$ and P365 (Fig. 1B; Table 1). At P540 the total population of $\mathrm{m}^{+}$RGCs was also slightly smaller than at P365, but this decrease did not reach statistical significance (Fig. 1B; Table 1).

The $\mathrm{m}^{+} \mathrm{RGCs}$ were not homogenously distributed in the retina; they were more abundant in the periphery and their highest density was found in the superotemporal retina (Figs 2, $3 \mathrm{~A}-\mathrm{C})$. This distribution varied between the left and right retina, the animals, and the ages studied. The topography was similar in $\mathrm{SD}$ and $\mathrm{P} 23 \mathrm{H}-1$ retinas, which indicated that $\mathrm{m}^{+} \mathrm{RGC}$ loss in the dystrophic animals occurred all across the retina. However, a quantitative analysis of the different retinal quadrants with time and in both strains showed that the decrease of $\mathrm{m}^{+}$RGCs in the $\mathrm{P} 23 \mathrm{H}-1$ rat retinas was significantly higher only in the superotemporal retina $(P<0.001$; ANOVA; Fig. 3$)$.

\section{Comparison of Brn3 $a^{+}$RGC and $m^{+}$RGC Loss in the P23H-1 Rat}

In the $\mathrm{P} 23 \mathrm{H}-1$ rat retina, $\mathrm{Brn} 3 \mathrm{a}^{+} \mathrm{RGCs}$ diminished by approximately $8.8 \%$ and $23.7 \%$ between $\mathrm{P} 30$ and $\mathrm{P} 365$ or between $\mathrm{P} 30$ and $\mathrm{P} 540$, respectively, while $\mathrm{m}^{+} \mathrm{RGCs}$ decreased by approximately $22.6 \%$ and $28.2 \%$ between the same periods (Fig
1; Table 1), and therefore, $\mathrm{m}^{+} \mathrm{RGC}$ loss occurred earlier than Brn $3 \mathrm{a}^{+} \mathrm{RGC}$ loss and reached higher proportions. However, when we compared the number of $\mathrm{Brn}_{3} \mathrm{a}^{+}$and $\mathrm{m}^{+} \mathrm{RGCs}$ found in $\mathrm{P} 540 \mathrm{P} 23 \mathrm{H}-1$ rat retinas to the number of the same cells found in control P540 SD rats, the differences found between the SD and the $\mathrm{P} 23 \mathrm{H}-1$ strain were similar for both types of cells (28.7\% and $27.2 \%$, respectively; Fig 1 ; Table 1$)$. Therefore, $\mathrm{m}^{+} \mathrm{RGC}$ loss and Brn $3 \mathrm{a}^{+} \mathrm{RGC}$ loss may occur in similar proportions in $\mathrm{P} 23 \mathrm{H}-1$ rats.

\section{Brn3a Expression by $\mathbf{m}^{+}$RGCs}

The number of $\mathrm{m}^{+} \mathrm{RGCs}$ that coexpressed Brn3a varied between animals and ages studied (Fig. 4; Table 2). In the control animals, there were similar numbers of coexpressing cells in all the quadrants, but in the $\mathrm{P} 23 \mathrm{H}-1$ rats there was a tendency for the coexpressing RGCs to be localized in the superior quadrants (data not shown).

In control SD rats we found that most of the $\mathrm{m}^{+} \mathrm{RGCs}$ were Brn3a negative (Fig. 4G; Table 2), since colocalization analyses showed that at $\mathrm{P} 30$ and $\mathrm{P} 540$ only $0.27 \%$ and $0.28 \%$, respectively, of the $\mathrm{m}^{+} \mathrm{RGCs}$ were also $\mathrm{Brn} 3 \mathrm{a}^{+}$. These data are in concordance with previous studies from our laboratory that show similar results in this and other rat strains. ${ }^{68-70}$ In P23H-1 rats, however, the number and percentage of $\mathrm{m}^{+} \mathrm{RGCs}$ that were also $\mathrm{Brn}_{3} \mathrm{a}^{+}$were significantly higher, already at P30 (3.31\%; Figs. 4A-C, 4G; Table 2). And, although at P365 and P540 the net number of Brn3a-expressing $\mathrm{m}^{+} \mathrm{RGCs}$ was not significantly higher than at $\mathrm{P} 30$, there was a significant increase in the percentage of $\mathrm{m}^{+} \mathrm{RGCs}$ that expressed Brn3a $3.86 \%$ at P365 and $10.65 \%$ at P540; Table 2). Thus, Brn3a expression by $\mathrm{m}^{+}$RGCs increased with age in the $\mathrm{P} 23 \mathrm{H}-1$ retina and, after photoreceptor degeneration, ${ }^{51,65}$ a higher proportion of surviving $\mathrm{m}^{+} \mathrm{RGCs}$ were also $\mathrm{Brn} 3 \mathrm{a}^{+}$.

\section{Degeneration of $\mathbf{m}^{+}$RGCs Dendritic Structure in P23H - 1 Rats}

The dendritic morphology and stratification pattern of the $\mathrm{m}^{+}$RGCs were analyzed in $\mathrm{P} 23 \mathrm{H}-1$ rats at $\mathrm{P} 365$ and $\mathrm{P} 540$ and compared with SD and $\mathrm{P} 23 \mathrm{H}-3$ rats of the same ages (Fig. 5). There were no differences in any of the analyzed parameters between the different $\mathrm{m}^{+} \mathrm{RGC}$ subtypes (M1, M1d, M2, M3), so the results from the three subtypes were averaged (Fig. 5).

In $\mathrm{P} 23 \mathrm{H}-1$ rats, the $\mathrm{m}^{+} \mathrm{RGCs}$ showed a decrease of arborization parameters with age. At P365, the $\mathrm{m}^{+} \mathrm{RGCs}$ showed a significant decrease of the dendritic area, number of branch points, number of terminal neurite tips per cell, and Sholl area when compared to the $\mathrm{m}^{+}$RGCs in P365 SD rats $(P<$ 0.001 , for dendritic area and Sholl area; and $P<0.05$, for branch points and terminal neurite tips). At P540, the $\mathrm{m}^{+} \mathrm{RGCs}$ of $\mathrm{P} 23 \mathrm{H}-1$ rats showed significantly smaller branching patterns than those obtained in P540 SD rats $(P<0.001$, for all parameters).

To study whether the severity of the degeneration of the outer retina influences the secondary degeneration of the $\mathrm{m}^{+} \mathrm{RGCs}$, the arborization patterns of $\mathrm{m}^{+} \mathrm{RGCs}$ were also analyzed in $\mathrm{P} 23 \mathrm{H}-3$ rats, which experience a slower degeneration of the outer retina. ${ }^{75}$ Surprisingly, no significant differences were found for any of the dendritic parameters analyzed between $\mathrm{P} 23 \mathrm{H}-1$ and $\mathrm{P} 23 \mathrm{H}-3$ rats $^{62}$ (Fig. 5). This indicates that the $\mathrm{m}^{+} \mathrm{RGCs}$ of $\mathrm{P} 23 \mathrm{H}-1$ rats experience degenerative changes in their arborization patterns similar to those previously observed in $\mathrm{P} 23 \mathrm{H}-3$ rats $^{62}$ (Fig. 5), and this suggests that degeneration of the dendritic arborization of $\mathrm{m}^{+} \mathrm{RGCs}$ is independent of the severity of photoreceptor degeneration. 

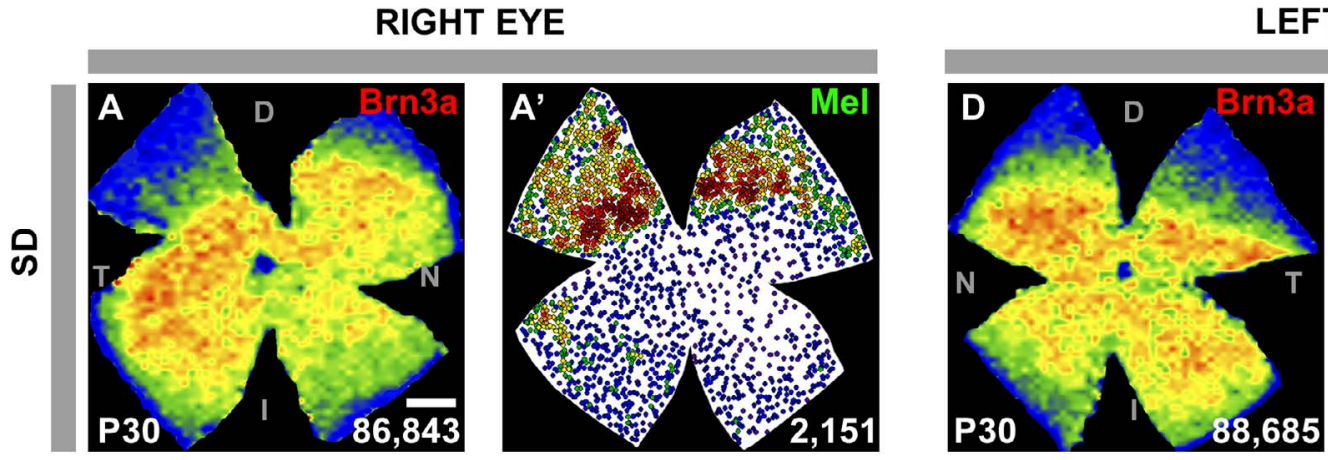

LEFT EYE
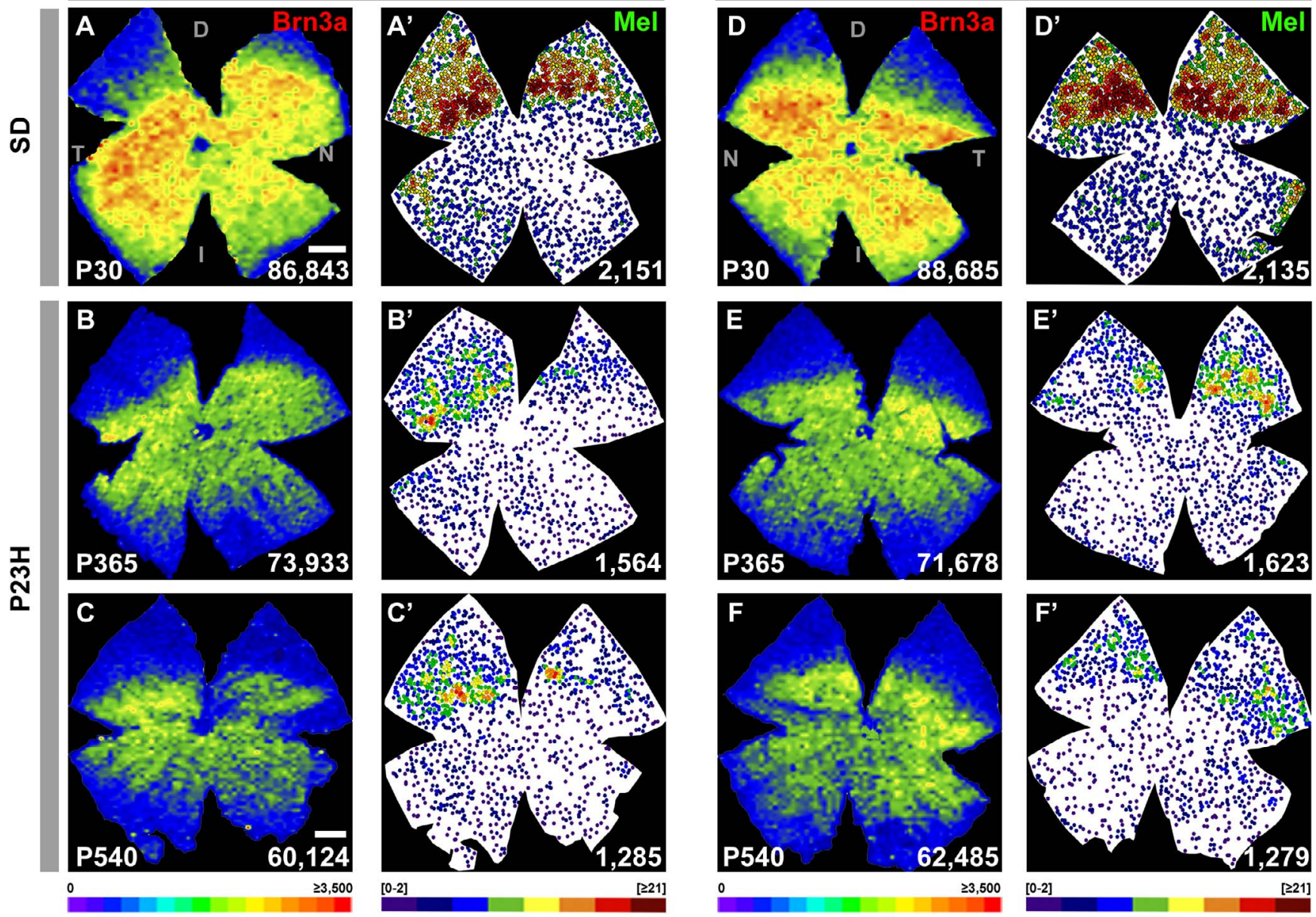

Figure 2. Brn $3 \mathrm{a}^{+}$RGC and $\mathrm{m}^{+} \mathrm{RGC}$ distribution. (A-F'): The RGC isodensity maps showing the distribution of Brn $3 \mathrm{a}^{+} \mathrm{RGCs}$ in P30 SD (A, D) and P365 and P540 P23H-1 (B, C, E, F) rat retinas. (A'-F') Neighbor maps showing the distribution of $\mathrm{m}^{+} \mathrm{RGCs}$ in the same retinas. The number of RGCs or $\mathrm{m}^{+} \mathrm{RGCs}$ is represented at the bottom of each map. Color scale bars at the bottom of the figure indicate from 0 (purple) to $\geq 3500$ (red) Brn3 $\mathrm{a}^{+} \mathrm{RGCs} / \mathrm{mm}^{2}$ in the RGC isodensity maps and from 0 to 2 (purple) to $\geq 21$ (dark brown) neighbors in a fixed radius in the ipRGC neighbor maps. I, inferior; Mel, melanopsin; N, nasal; S, superior; T, temporal. Scale bars: $1 \mathrm{~mm}$.

In conclusion, we did not find significant dendritic changes with age in SD rats but we found a significant decrease of all the dendritic parameters analyzed between P30 and P365 and some additional changes between P365 and P540 in both dystrophic strains (Figs. 5G-J). This indicates that in the $\mathrm{P} 23 \mathrm{H}$ strain, there was dendritic degeneration of the $\mathrm{m}^{+} \mathrm{RGCs}$ that worsened with age.

\section{Discussion}

The ipRGCs serve many light-mediated functions, such as the regulation of the circadian rhythms. The sleep-wake cycle is mediated by these cells ${ }^{13}$ and may be affected by diseases that course with optic nerve or retinal degeneration. ${ }^{85}$ In fact, it has been shown that most RP patients experience sleep disturbances $^{59-61}$ and also show signs of RGC degeneration. ${ }^{41-46}$ Other neurodegenerative diseases, such as Parkinson and Alzheimer's disease, are also associated with sleep disturbances, ${ }^{86-90}$ and recently it has been shown that they course also with RGC degeneration. ${ }^{91-95}$ Interestingly, it has been proposed that ipRGCs survive better under different pathologic and experimental conditions ${ }^{19,32,33}$ and may have different requirements for survival after injury ${ }^{19,32,33}$; thus, it is important to study what happens to these neurons in these disease states.

The data in this work indicated that ipRGCs degenerate in a higher or similar proportion to the other RGCs after photoreceptor degeneration and show changes of their morphologic and molecular phenotype, perhaps in an attempt to resist the inherited retinal degeneration.

\section{Effect of Photoreceptor Degeneration on ipRGC Population}

In humans and animals, several studies ${ }^{41,43-48,50-54,96,97}$ have shown that photoreceptor degeneration leads, with time, to alterations of all the retinal layers independently of the etiology of the degeneration. Our studies have documented that both inherited and induced photoreceptor loss results in secondary RGC degeneration ${ }^{50-53}$; and we have proposed that it is due wholly or partly to axonal injury by the displaced retinal vessels in the course of retinal degeneration. ${ }^{48,50-53}$ However, it was not known whether the ipRGCs were also affected in our retinal degenerative models.

In this work, we studied $\mathrm{m}^{+} \mathrm{RGCs}$ in SD control and $\mathrm{P} 23 \mathrm{H}-1$ and $\mathrm{P} 23 \mathrm{H}-3$ rats that experience the same type of inherited photoreceptor degeneration, a form of rhodopsin mutation 

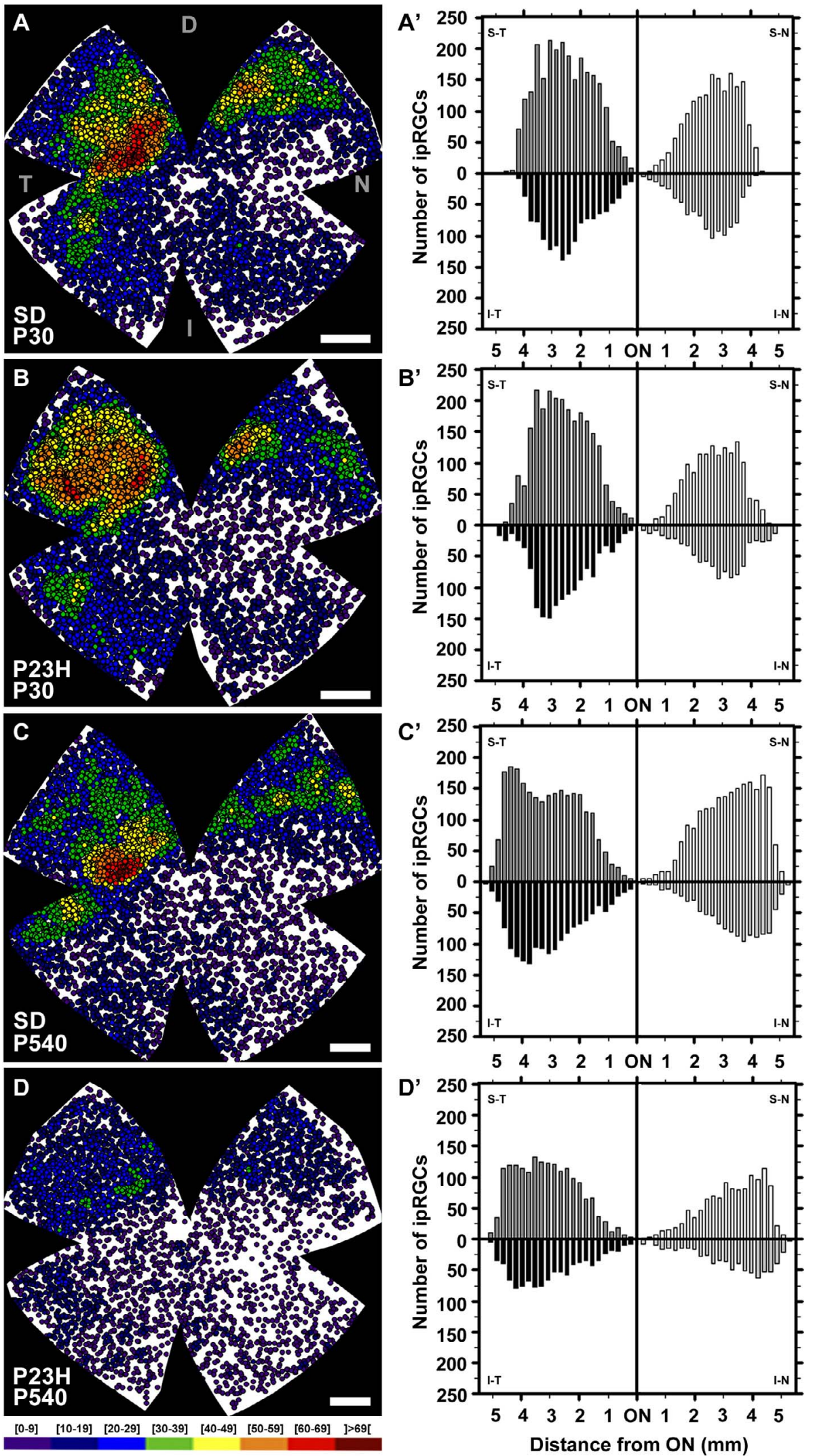

Figure 3. Analysis of the retinal distribution of $m^{+} R G C s$ in young and old control and P23H-1 rats. (A-D) Normalized $m^{+}$RGC neighbor maps constructed with pooled data from three SD retinas at P30 (A) and P540 (C) and three P23H-1 retinas at P30 (B) and P540 (D). The number of $\mathrm{m}^{+} \mathrm{RGCs}$ located at a given distance from the ON in these maps was plotted for each of the four retinal quadrants (A'-D'): superotemporal (S-T), superonasal (S-N), inferotemporal (I-T), and inferonasal (I-N). Color scale indicates from 0 to 3 (purple) to $\geq 69$ (red) $\mathrm{m}^{+} \mathrm{RGC}$ neighbors. Scale bars: $1 \mathrm{~mm}$. ON, optic nerve. 

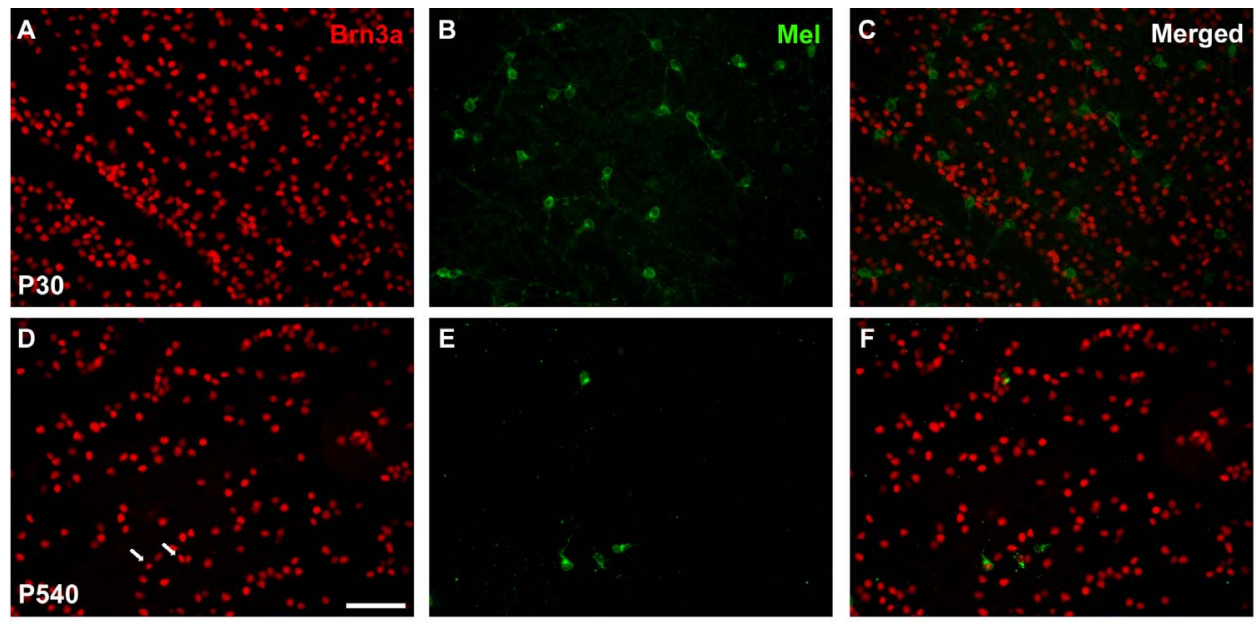

G

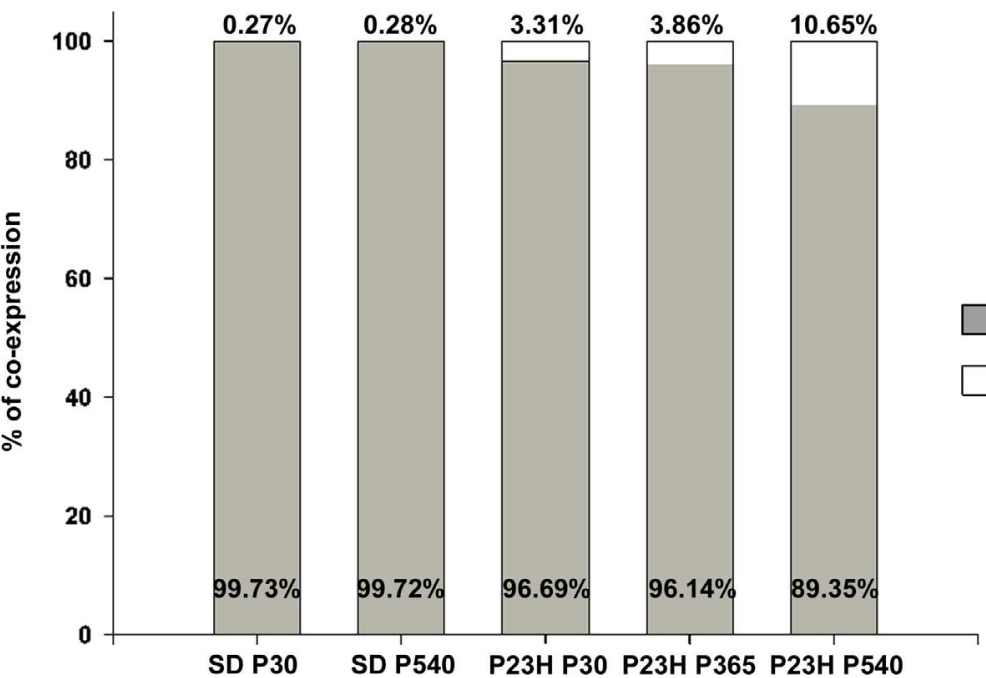

Brn3a-ipRGCs

Brn3a+ipRGCs

Figure 4. Expression of Brn3a by $\mathrm{m}^{+}$RGCs. (A-F) Individual photomicrographs taken from a control P30 SD rat (A-C) and a P540 P23H-1 rat (D-F) flat-mounted retina. In these retinas, Brn3a (red) $(\mathbf{A}, \mathbf{C})$ and melanopsin $(\mathrm{Mel}$; green $)(\mathbf{B}, \mathbf{E})$ were doubly immunodetected. The last column $(\mathbf{C}, \mathbf{F})$ corresponds to the merged images of the first two columns. The two doubly labeled ipRGCs in the P540 P23H-1 retina are shown by arrows in (D). (G) Stacked-bar graph showing the percentage of coexpression of Brn3a and melanopsin by ipRGCs in SD and P23H-1 rats at different postnatal times from 30 to 540 days. Scale bar for (A-F) in D: $50 \mu \mathrm{m}$.

commonly observed in human RP. The mean number and distribution of $\mathrm{m}^{+} \mathrm{RGCs}$ that we reported in this work in control SD animals and in young $\mathrm{P} 23 \mathrm{H}-1$ animals are similar to those reported in previous studies. $6,68,70$ But we also document here for the first time in $\mathrm{P} 23 \mathrm{H}-1$ rats a significant decrease of the $\mathrm{m}^{+}$RGCs between $\mathrm{P} 30$ and $\mathrm{P} 365$. A recent study performed on $\mathrm{P} 23 \mathrm{H}-3$ rats, which experience a slower retinal degenera- tion than P23H-1 rats (for review see Pennesi et al. ${ }^{75}$ ), has shown that the $\mathrm{m}^{+} \mathrm{RGCs}$ in these animals are first reduced significantly at $\mathrm{P} 540 .^{62}$ It is possible that because the $\mathrm{P} 23 \mathrm{H}-3$ rats experience a slower retinal degeneration, their RGCs, including the $\mathrm{m}^{+} \mathrm{RGCs}$, may also degenerate more slowly. However, in the previous study, loss of $67 \%$ of the $\mathrm{m}^{+} \mathrm{RGCs}$ is found between P30 and P540, ${ }^{62}$ whereas in our study we

TABLE 2. Brn3a Expression by $\mathrm{m}^{+}$RGCs in Sprague-Dawley and P23H-1 rats at Different Postnatal Days

\begin{tabular}{lrlcr}
\hline Strain & Postnatal Time & \multicolumn{1}{c}{ No. of $\mathbf{~ m}^{+}$RGCs } & No. of $\mathbf{m}^{+}$RGCs That Express Brn3a & Percentage of coexpression \\
\hline SD & P30 $(n=10$ retinas $)$ & $6065(600 \pm 77,56$ per retina $)$ & $17(1.7 \pm 0.95$ per retina $)$ & 0.27 \\
& P540 $(n=10$ retinas $)$ & $6457(619 \pm 66,97$ per retina $)$ & $18(1.8 \pm 0.63$ per retina $)$ & 0.28 \\
P23H & P30 $(n=10$ retinas $)$ & $6557(656 \pm 92,01$ per retina $)$ & $217(18.08 \pm 12.17$ per retina $) \dagger$ & $3.31 \dagger$ \\
& P365 $(n=10$ retinas $)$ & $4582(427 \pm 53,62 \text { per retina })^{*} \dagger$ & $177(16.09 \pm 6.85$ per retina $) \dagger$ & $3.86 \dagger$ \\
& P540 $(n=10$ retinas $)$ & $2693(270 \pm 62,57 \text { per retina })^{*} \dagger$ & $287(28.7 \pm 10.23 \text { per retina })^{*} \dagger$ & $10.65^{*} \dagger$
\end{tabular}

The total number of $\mathrm{m}^{+} \mathrm{RGCs}$ counted in 20 standard areas of each retina at every age analyzed is shown in the third column. The fourth column shows the number of these cells that were also $\mathrm{Brn}_{3} \mathrm{a}^{+}$. The last column shows the percentage of melanopsin and Brn3a coexpression, considering as $100 \%$ the total number of $\mathrm{m}^{+} \mathrm{RGCs}$ counted at each age. In parenthesis are shown the number of retinas analyzed and the mean number of cells \pm SD counted in each retina.

${ }^{*} P \leq 0.05$ when compared to earlier ages in the same strain (Mann-Whitney test).

$\dagger P \leq 0.001$ when compared to control P30 SD rats (Mann-Whitney test). 

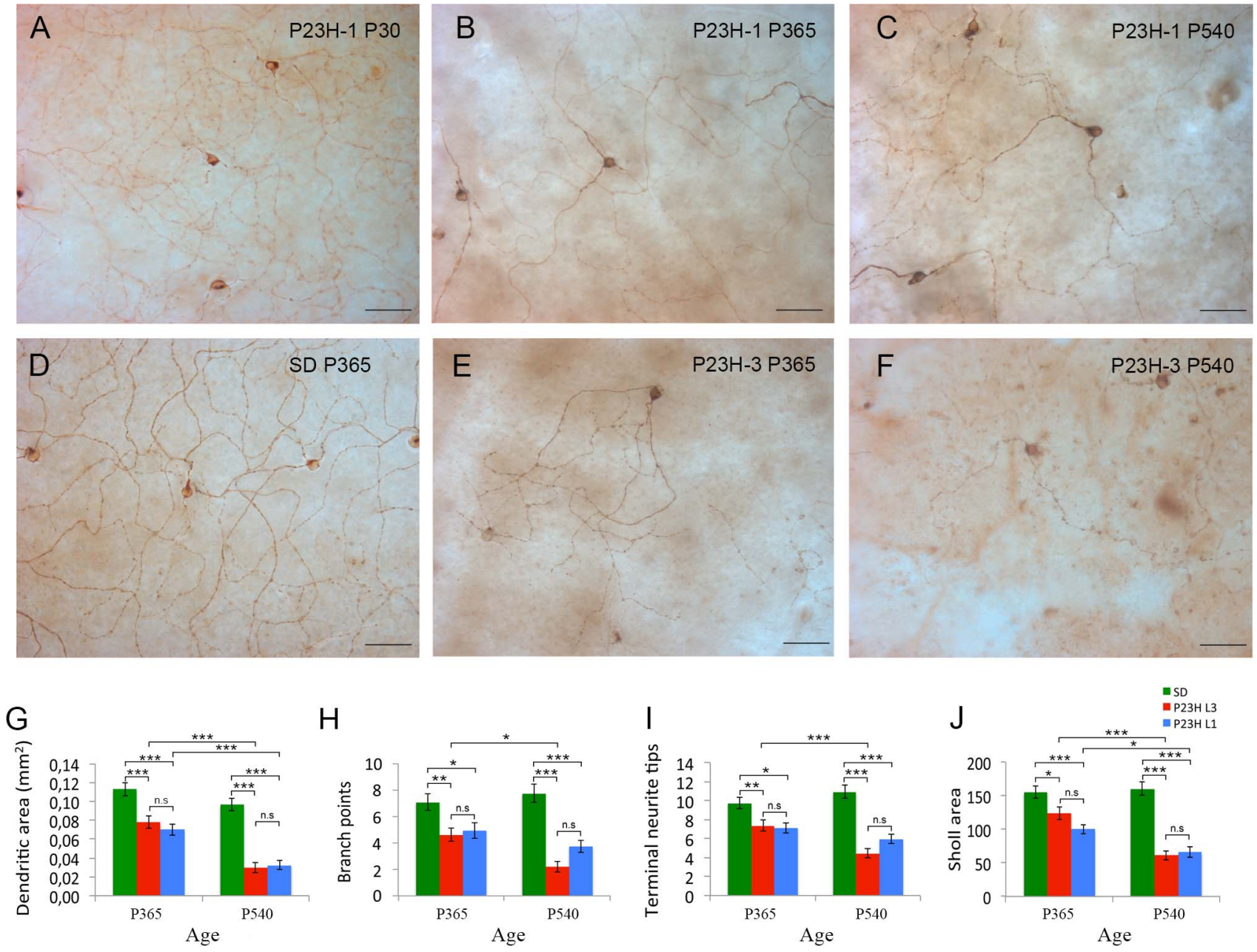

Figure 5. Degeneration of $\mathrm{m}^{+} \mathrm{RGCs}$ in the $\mathrm{P} 23 \mathrm{H}$ retina. Representative examples of $\mathrm{M} 1 \mathrm{~m}^{+} \mathrm{RGCs}$ from $\mathrm{P} 30, \mathrm{P} 365$, and $\mathrm{P} 540 \mathrm{P} 23 \mathrm{H}-1$ rats (A-C), $\mathrm{P} 365$ SD rats (D), and P365 and P540 P23H-3 rats (E, F). Bar graphs showing the morphometric dendritic parameters of the $\mathrm{m}^{+} \mathrm{RGCs}$ in $\mathrm{P} 365$ and $\mathrm{P} 540$ SD, P23H-3, and P23H-1 retinas (G-J): mean dendritic area (G), number of branch points $(\mathbf{H})$, number of terminal neurite tips per cell (I), and Sholl area $(\mathbf{J}) .{ }^{*} P<0.05,{ }^{*} P<0.01,{ }^{*} * P<0.001$; ANOVA. Scale bars: $50 \mu \mathrm{m}(\mathbf{A}-\mathbf{F})$.

found a loss of only $27.2 \%$ during the same time period. This discrepancy may be due to differences in the methods used. Other authors have also found significant loss of $\mathrm{m}^{+} \mathrm{RGCs}$ in other animal models of retinal degeneration, namely, the RCS $\mathrm{rat}^{63}$ and the $\mathrm{rd} / \mathrm{rd} \mathrm{cl}$ mouse, ${ }^{12}$ a mouse lacking both rods and cones. Thus, it is clear from this and other studies that the number of $\mathrm{m}^{+} \mathrm{RGCs}$ decreases with age in the retinas of rodents with inherited photoreceptor degeneration.

Because we have used immunodetection with antibodies against melanopsin to detect the ipRGCs, it is possible that the observed loss of $\mathrm{m}^{+} \mathrm{RGCs}$ represents only a decreased expression of this protein by these cells. Two previous studies have shown that melanopsin mRNA decreases in ipRGCs after $\mathrm{N}$-methyl-N-nitrosourea-induced ${ }^{98}$ or after naturally occurring photoreceptor degeneration. ${ }^{99}$ However, both melanopsin and Brn3a have been shown to be expressed by RGCs for long periods of time after injury. ${ }^{21,71,100}$ Moreover, in this study we found that the percentage of $\mathrm{m}^{+} \mathrm{RGCs}$ loss was similar to the percentage of $\mathrm{Brn}_{3} \mathrm{a}^{+} \mathrm{RGC}$ loss, and we have shown in previous studies that there is RGC loss with age in the $\mathrm{P} 23 \mathrm{H}-1$ rat, and thus we think that the loss of $\mathrm{m}^{+} \mathrm{RGCs}$ that we documented in this study is real.

It is known that density, wholeness, and dendritic arborization of ipRGCs decrease in advanced stages of degenerative disease in $\mathrm{P} 23 \mathrm{H}-3$ rats, ${ }^{62}$ but whether this was true in the P23H-1 rat line was not known. In this work, we showed that despite the faster degeneration of the outer nuclear layer in the $\mathrm{P} 23 \mathrm{H}-1$ than the $\mathrm{P} 23 \mathrm{H}-3$ line,${ }^{78,101}$ the morphologic parameters of the $\mathrm{m}^{+} \mathrm{RGC}$ dendrites deteriorated similarly in both lines and worsened with age. This is in agreement with previous studies showing that $\mathrm{m}^{+} \mathrm{RGCs}$ are more resistant to injury, despite the advanced stage of some retinal degenerations. ${ }^{19-21,31,102}$

\section{Melanopsin-Positive RGCs Change Their Brn3a Coexpression During Photoreceptor Degeneration}

In this work we also documented, for the first time in $\mathrm{P} 23 \mathrm{H}-1$ rats, a change with age in the expression of Brn3a by $\mathrm{m}^{+} \mathrm{RGCs}$. We observed a higher coexpression of Brn3a and melanopsin in young $\mathrm{P} 23 \mathrm{H}-1$ animals $(3.30 \%$, as opposed to $0.27 \%$ in SD) and also an increase in these proportions as photoreceptor degeneration progresses (up to $10.65 \%$ at P540). Approximately 600 cells ( $28.2 \%$ of the $\mathrm{m}^{+} \mathrm{RGCs}$ ) were lost between $\mathrm{P} 30$ and $\mathrm{P} 540$ in $\mathrm{P} 23 \mathrm{H}-1$ rats, and $10.65 \%$ coexpressed both markers (approximately 150 cells) at P540. This increased coexpression may be explained by a phenotypic change, an increased expression of this transcription factor in the population of surviving $\mathrm{m}^{+} \mathrm{RGCs}$, or, alternatively, preferential survival of the $\mathrm{m}^{+} \mathrm{RGCs}$ that express Brn3a. This latter possibility implies that 
$\mathrm{m}^{+} \mathrm{RGCs}$ that express Brn3a are more resistant to photoreceptor degeneration than those that do not express it. It is tempting to speculate that such an increased survival may be related to the antiapoptotic properties associated with Brn3a $\mathrm{a}^{103-108}$ and thus, this change would make them more resistant to photoreceptor degeneration and/or axonal injury. ${ }^{51}$

It has been recently proposed that ipRGCs may play a role in image formation ${ }^{13}$ and in mice, $\mathrm{m}^{+} \mathrm{RGCs}$ coexpresing Brn $3 \mathrm{~b}$ are thought to be responsible for such a function. ${ }^{109,110}$ It is tempting to speculate that such a change in Brn3a expression in the $\mathrm{P} 23 \mathrm{H}$ rats may reflect an increase in vision through $\mathrm{m}^{+} \mathrm{RGCs}$ to compensate for the loss of photoreceptors, because (1) in mice, ectopic expression of melanopsin in RGCs enhances the visual function after photoreceptor degeneration ${ }^{111}$; (2) in the adult rat, approximately $90 \%$ of $\mathrm{m}^{+}$RGCs project their axons to the $\mathrm{SCi}^{68}$ the main imageforming visual retinorecipient nuclei in rodents; and (3) in rat, Brn3a is the dominating member of the Brn3 family, ${ }^{69,70}$ while in mice, $\mathrm{Brn} 3 \mathrm{~b}$ is the $\mathrm{Brn} 3$ member needed for RGC differentiation and survival. ${ }^{112}$ Thus, it is possible that in rat the $\mathrm{m}^{+} \mathrm{RGCs}$ in charge of image-forming visual functions are those expressing Brn3a instead of Brn3b as proposed for mice. ${ }^{109,110}$

In summary, this study demonstrated in a rat model of RP that after a complete loss of photoreceptors, both $\mathrm{m}^{+} \mathrm{RGCs}$ and Brn $3 \mathrm{a}^{+} \mathrm{RGCs}$ are affected in similar proportions. Thus, in the presently studied inherited retinal degeneration, $\mathrm{m}^{+} \mathrm{RGCs}$ did not appear to be more resistant than the rest of the RGC population. We also showed a decrease of the dendritic morphologic parameters and increased coexpression of melanopsin and Brn3a in the surviving $\mathrm{m}^{+} \mathrm{RGCs}$, phenotypic and molecular changes that indicate an adaptive response to resist injury and/or change of function of these cells as photoreceptors die. Further studies are needed to clarify the role of $\mathrm{m}^{+} \mathrm{RGCs}$ in inherited retinal degeneration and other neurodegenerative disorders

\section{Acknowledgments}

Supported by grants from the Spanish Ministry of Economy and Competitiveness: SAF-2012-38328; ISCIII-FEDER "Una manera de hacer Europa" PI13/00643, PI13/01266, and BFU2012-36845, RETICS: RD12/0034/0014, and RD12/0034/0010.

Disclosure: D. García-Ayuso, None; J. Di Pierdomenico, None; G. Esquiva, None; F.M. Nadal-Nicolás, None; I. Pinilla, None; N. Cuenca, None; M. Vidal-Sanz, None; M. Agudo-Barriuso, None; M.P. Villegas Pérez, None

\section{References}

1. Berson DM, Dunn FA, Takao M. Phototransduction by retinal ganglion cells that set the circadian clock. Science. 2002;295: 1070-1073.

2. Kumbalasiri T, Provencio I. Melanopsin and other novel mammalian opsins. Exp Eye Res. 2005;81:368-375.

3. Provencio I, Rodriguez IR, Jiang G, Hayes WP, Moreira EF, Rollag MD. A novel human opsin in the inner retina. $J$ Neurosci. 2000;20:600-605.

4. Provencio I, Rollag MD, Castrucci AM. Photoreceptive net in the mammalian retina: this mesh of cells may explain how some blind mice can still tell day from night. Nature. 2002; 415:493.

5. Berson DM. Strange vision: ganglion cells as circadian photoreceptors. Trends Neurosci. 2003;26:314-320.

6. Hattar S, Liao HW, Takao M, Berson DM, Yau KW. Melanopsincontaining retinal ganglion cells: architecture, projections, and intrinsic photosensitivity. Science. 2002;295:1065-1070.
7. Hattar S, Lucas RJ, Mrosovsky N, et al. Melanopsin and rodcone photoreceptive systems account for all major accessory visual functions in mice. Nature. 2003;424:76-81.

8. Hankins MW, Peirson SN, Foster RG. Melanopsin: an exciting photopigment. Trends Neurosci. 2008;31:27-36.

9. Lucas RJ, Hattar S, Takao M, Berson DM, Foster RG, Yau KW. Diminished pupillary light reflex at high irradiances in melanopsin-knockout mice. Science. 2003;299:245-247.

10. Panda S, Provencio I, Tu DC, et al. Melanopsin is required for non-image-forming photic responses in blind mice. Science. 2003;301:525-527.

11. Semo M, Gias C, Ahmado A, Vugler A. A role for the ciliary marginal zone in the melanopsin-dependent intrinsic pupillary light reflex. Exp Eye Res. 2014;119:8-18.

12. Vugler A, Semo M, Ortín-Martínez A, et al. A role for the outer retina in development of the intrinsic pupillary light reflex in mice. Neuroscience. 2015;286:60-78.

13. Schmidt TM, Chen SK, Hattar S. Intrinsically photosensitive retinal ganglion cells: many subtypes, diverse functions. Trends Neurosci. 2011;34:572-580.

14. Schmidt TM, Alam NM, Chen S, et al. A role for melanopsin in alpha retinal ganglion cells and contrast detection. Neuron. 2014;82:781-788.

15. Estevez ME, Fogerson PM, Ilardi MC, et al. Form and function of the M4 cell, an intrinsically photosensitive retinal ganglion cell type contributing to geniculocortical vision. J Neurosci. 2012;32:13608-13620.

16. Allen AE, Storchi R, Martial FP, et al. Melanopsin-driven light adaptation in mouse vision. Curr Biol. 2014;21:2481-2490.

17. Güler AD, Ecker JL, Lall GS, et al. Melanopsin cells are the principal conduits for rod-cone input to non-image-forming vision. Nature. 2008;453:102-105.

18. Semo M, Gias C, Ahmado A, et al. Dissecting a role for melanopsin in behavioural light aversion reveals a response independent of conventional photoreception. PLoS One. 2010;5:e15009.

19. Cui Q, Ren C, Sollars PJ, Pickard GE, So KF. The injury resistant ability of melanopsin-expressing intrinsically photosensitive retinal ganglion cells. Neuroscience. 2015;22:845853.

20. Robinson G, Madison RD. Axotomized mouse retinal ganglion cells containing melanopsin show enhanced survival, but not enhanced axon regrowth into a peripheral nerve graft. Vision Res. 2004;44:2667-2674

21. Pérez de Sevilla Müller L, Sargoy A, Rodriguez AR, Brecha NC. Melanopsin ganglion cells are the most resistant retinal ganglion cell type to axonal injury in the rat retina. PLoS One. 2014;9:e93274.

22. DeParis S, Caprara C, Grimm C. Intrinsically photosensitive retinal ganglion cells are resistant to $\mathrm{N}$-methyl-D-aspartic acid excitotoxicity. Mol Vis. 2012;18:2814-2827.

23. Moura AL, Nagy BV, La Morgia C, et al. The pupil light reflex in Leber's hereditary optic neuropathy: evidence for preservation of melanopsin-expressing retinal ganglion cells. Invest Ophthalmol Vis Sci. 2013;54:4471-4477.

24. Pérez-Rico C, de la Villa P, Arribas-Gómez I, Blanco R. Evaluation of functional integrity of the retinohypothalamic tract in advanced glaucoma using multifocal electroretinography and light-induced melatonin suppression. Exp Eye Res. 2010;91:578-583.

25. Nissen C, Sander B, Milea D, et al. Monochromatic pupillometry in unilateral glaucoma discloses no adaptive changes subserved by the ipRGCs. Front Neurol. 2014;5:15.

26. Kankipati L, Girkin CA, Gamlin PD. The post-illumination pupil response is reduced in glaucoma patients. Invest Ophthalmol Vis Sci. 2011;52:2287-2292. 
27. Feigl B, Mattes D, Thomas R, Zele AJ. Intrinsically photosensitive (melanopsin) retinal ganglion cell function in glaucoma. Invest Ophthalmol Vis Sci. 2011;52:4362-4367.

28. Drouyer E, Dkhissi-Benyahya O, Chiquet C, et al. Glaucoma alters the circadian timing system. PLoS One. 2008;3:e3931.

29. de Zavalía N, Plano SA, Fernandez DC, et al. Effect of experimental glaucoma on the non-image forming visual system. J Neurochem. 2011;117:904-914.

30. Zhang Q, Vuong H, Huang X, et al. Melanopsin-expressing retinal ganglion cell loss and behavioral analysis in the Thy1CFP-DBA/2J mouse model of glaucoma. Sci China Life Sci. 2013;56:720-730.

31. Li RS, Chen B-Y, Tay DK, Chan HHL, Pu M-L, So K-F. Melanopsin-expressing retinal ganglion cells are more injuryresistant in a chronic ocular hypertension model. Invest Ophthalmol Vis Sci. 2006;47:2951-2958.

32. Valiente-Soriano FJ, Salinas-Navarro M, Jiménez López M, et al. Effects of ocular hypertension in the visual system of pigmented mice. PLoS One. 2015;10:e0121134.

33. Valiente-Soriano FJ, Nadal-Nicolás FM, Salinas-Navarro M, et al. BDNF rescues RGCs but not ipRGCs in ocular hypertensive albino rat retinas. Invest Ophthalmol Vis Sci. 2015;56: 1924-1936.

34. Baehr W, Frederick JM. Naturally occurring animal models with outer retina phenotypes. Vision Res. 2009;49:26362652.

35. Daiger SP, Sullivan LS, Bowne SJ. Genes and mutations causing retinitis pigmentosa. Clin Genet. 2013;84:132-141.

36. Mohand-Said S, Hicks D, Dreyfus H, Sahel JA. Selective transplantationof rods delays cone loss in a retinitis pigmentosa model. Arch Ophthalmol. 2000;118:807-811.

37. Shen J, Yang X, Dong A. at al. Oxidative damage is a potential cause of cone cell death in retinitis pigmentosa. $J$ Cell Physiol. 2005;203:457-464.

38. Komeima K, Rogers BS, Lu L, Campochiaro PA. Antioxidants reduce cone cell death in a model of retinitis pigmentosa. Proc Natl Acad Sci U S A. 2006;103:11300-11305.

39. Stone JL, Barlow WE, Humayun MS, de Juan E Jr, Milam AH. Morphometric analysis of macular photoreceptors and ganglion cells in retinas with retinitis pigmentosa. Arch Ophthalmol. 1992;110:1634-1639.

40. Santos A, Humayun MS, de Juan E Jr, et al. Preservation of the inner retina in retinitis pigmentosa a morphometric analysis. Arch Ophthalmol. 1997;115:511-515.

41. Walia S, Fishman GA, Edward DP, Lindeman M. Retinal nerve fiber layer defects in RP patients. Invest Ophthalmol Vis Sci. 2007; $48: 4748-4752$.

42. Lim JI, Tan O, Fawzi AA, Hopkins JJ, Gil-Flamer JH, Huang D. A pilot study of Fourier-domain optical coherence tomography of retinal dystrophy patients. J Ophthalmol. 2008;146: 417-426.

43. Walia S, Fishman GA. Retinal nerve fiber layer analysis in RP patients using Fourier-domain OCT. Invest Ophthalmol Vis Sci. 2008;49:3525-3528.

44. Eng JG, Agrawal RN, Tozer KR, et al. Morphometric analysis of optic nerves and retina from an end-stage retinitis pigmentosa patient with an implanted active epiretinal array. Invest Ophthalmol Vis Sci. 2011;52:4610-4616.

45. Garcia-Martin E, Pinilla I, Sancho E, et al. Optical coherence tomography in retinitis pigmentosa: reproducibility and capacity to detect macular and retinal nerve fiber layer thickness alterations. Retina. 2012;32:1581-1591.

46. Anastasakis A, Genead MA, McAnany JJ, Fishman GA. Evaluation of retinal nerve fiber layer thickness in patients with retinitis pigmentosa using spectral-domain optical coherence tomography. Retina. 2012;32:358-363.
47. Villegas-Pérez MP, Vidal-Sanz M, Lund RD. Mechanism of retinal ganglion cell loss in inherited retinal dystrophy. Neuroreport. 1996;7:1995-1999.

48. Villegas-Pérez MP, Lawrence JM, Vidal-Sanz M, Lavail MM, Lund RD. Ganglion cell loss in RCS rat retina: a result of compression of axons by contracting intraretinal vessels linked to the pigment epithelium. J Comp Neurol. 1998;392: 58-77.

49. Wang S, Villegas-Pérez MP, Holmes T, et al. Evolving neurovascular relationships in the RCS rat with age. Curr Eye Res. 2003;27:183-196.

50. Marco-Gomariz MA, Hurtado-Montalbán N, Vidal-Sanz M, Lund RD, Villegas-Pérez MP. Phototoxic induced photoreceptor degeneration causes retinal ganglion cell degeneration in pigmented rats. J Comp Neurol. 2006;498:163-179.

51. García-Ayuso D, Salinas-Navarro M, Agudo M, et al. Retinal ganglion cell numbers and delayed retinal ganglion cell death in the P23H rat retina. Exp Eye Res. 2010;91:800-810.

52. García-Ayuso D, Salinas-Navarro M, Agudo-Barriuso M, Alarcón-Martínez L, Vidal-Sanz M, Villegas-Pérez MP. Retinal ganglion cell axonal compression by retinal vessels in lightinduced retinal degeneration. Mol Vis. 2011;17:1716-1733.

53. García-Ayuso D, Salinas-Navarro M, Nadal-Nicolás FM, et al. Sectorial loss of retinal ganglion cells in inherited photoreceptor degeneration is due to RGC death. Br J Ophthalmol. 2014;98:396-401.

54. Marc RE, Jones BW, Watt CB, Strettoi E. Neural remodeling in retinal degeneration. Prog Retin Eye Res. 2003;22:607-655.

55. Cuenca N, Fernández-Sánchez L, Campello L, et al. Cellular responses following retinal injuries and therapeutic approaches for neurodegenerative diseases. Prog Retin Eye Res. 2014;43:17-75.

56. Lax P, Otalora BB, Esquiva G, Rol Mde L, Madrid JA, Cuenca N. Circadian dysfunction in $\mathrm{P} 23 \mathrm{H}$ rhodopsin transgenic rats: effects of exogenous melatonin. J Pineal Res. 2011;50:183191.

57. Lupi D, Semo M, Foster RG. Impact of age and retinal degeneration on the light input to circadian brain structures. Neurobiology. 2012;33:383-392.

58. Ruggiero L, Allen CN, Brown RL, Robinson DW. The development of melanopsin-containing retinal ganglion cells in mice with early retinal degeneration. Eur $J$ Neurosci. 2009;29:359-367.

59. Flynn-Evans EE, Tabandeh H, Skene DJ, Lockley SW. Circadian rhythm disorders and melatonin production in 127 blind women with and without light perception. J Biol Rhythms. 2014;29:215-224.

60. Gordo MA, Recio J, Sánchez-Barceló EJ. Decreased sleep quality in patients suffering from retinitis pigmentosa. J Sleep Res. 2001;10:159-164.

61. Ionescu D, Driver HS, Heon E, Flanagan J, Shapiro CM. Sleep and daytime sleepiness in retinitis pigmentosa patients. $J$ Sleep Res. 2001;10:329-335.

62. Esquiva G, Lax P, Cuenca N. Impairment of intrinsically photosensitive retinal ganglion cells associated with late stages of retinal degeneration. Invest Ophthalmol Vis Sci. 2013;54:4605-4618.

63. Vugler AA, Semo M, Joseph A, Jeffery G. Survival and remodeling of melanopsin cells during retinal dystrophy. Vis Neurosci. 2008;25:125-138.

64. Mazzoni F, Novelli E, Strettoi E. Retinal ganglion cells survive and maintain normal dendritic morphology in a mouse model of inherited photoreceptor degeneration. J Neurosci. 2008; 28:14282-14292.

65. García-Ayuso D, Ortín-Martínez A, Jiménez-López M, et al. Changes in the photoreceptor mosaic of $\mathrm{P} 23 \mathrm{H}-1$ rats during retinal degeneration: implications for rod-cone dependent survival. Invest Ophthalmol Vis Sci. 2013;54:5888-5900. 
66. Dryja TP, McGee TL, Reichel E, et al. A point mutation of the rhodopsin gene in one form of retinitis pigmentosa. Nature. 1990;25:364-366.

67. Ferrari S, Di Iorio E, Barbaro V, Ponzin D, Sorrentino FS, Parmeggiani F. Retinitis pigmentosa: genes and disease mechanisms. Curr Genomics. 2011;12:238-249.

68. Galindo-Romero C, Jiménez-López M, García-Ayuso D, et al. Number and spatial distribution of intrinsically photosensitive retinal ganglion cells in the adult albino rat. Exp Eye Res. 2013;108:84-93.

69. Nadal-Nicolas FM, Jimenez-Lopez M, Salinas-Navarro M, et al. Whole number, distribution and co-expression of Brn3 transcription factors in retinal ganglion cells of adult albino and pigmented rats. PLoS One. 2012;7:e49830.

70. Nadal-Nicolás FM, Salinas-Navarro M, Jiménez-López M, et al. Displaced retinal ganglion cells in albino and pigmented rats. Front Neuroanat. 2014;8:99.

71. Galindo-Romero C, Avilés-Trigueros M, Jiménez-López M, et al. Axotomy-induced retinal ganglion cell death in adult mice: quantitative and topographic time course analyses. Exp Eye Res. 2011;92:377-387.

72. Nadal-Nicolas FM, Jimenez-Lopez M, Sobrado-Calvo P, et al. $\mathrm{Brn} 3 \mathrm{a}$ as a marker of retinal ganglion cells: qualitative and quantitative time course studies in naive and optic nerveinjured retinas. Invest Ophthalmol Vis Sci. 2009;50:38603868.

73. Valiente-Soriano FJ, García-Ayuso D, Ortín-Martínez A, et al. Distribution of melanopsin positive neurons in pigmented and albino mice: evidence for melanopsin interneurons in the mouse retina. Front Neuroanat. 2014;8:131.

74. Salinas-Navarro M, Jimenez-Lopez M, Valiente-Soriano FJ, et al. Retinal ganglion cell population in adult albino and pigmented mice: a computerized analysis of the entire population and its spatial distribution. Vis Res. 2009;49: 637-647.

75. Pennesi ME, Nishikawa S, Matthes MT, Yasumura D, LaVail MM. The relationship of photoreceptor degeneration to retinal vascular development and loss in mutant rhodopsin transgenic and RCS rats. Exp Eye Res. 2008;87:561-570.

76. Olsson JE, Gordon JW, Pawlyk BS, et al. Transgenic mice with a rhodopsin mutation (Pro23His): A mouse model of autosomal dominant retinitis pigmentosa. Neuron. 1992;9: 815-830.

77. Cuenca N, Pinilla I, Sauvé Y, Lu B, Wang S, Lund RD. Regressive and reactive changes in the connectivity patterns of rod and cone pathways of $\mathrm{P} 23 \mathrm{H}$ transgenic rat retina. Neuroscience. 2004;127:301-317.

78. Fernández-Sánchez L, Lax P, Esquiva G, Martín-Nieto J, Pinilla I, Cuenca N. Safranal, a Saffron Constituent, Attenuates Retinal Degeneration in P23H Rats. PLoS One. 2012;7: e43074.

79. González-Menéndez I, Contreras F, Cernuda-Cernuda R, Garcia-Fernandez JM. Daily rhythm of melanopsin-expressing cells in the mouse retina. Front Cell Neurosci. 2009;3:3.

80. Hannibal J, Georg B, Fahrenkrug J. Differential expression of melanopsin mRNA and protein in Brown Norwegian rats. Exp Eye Res. 2013;106:55-63.

81. Salinas-Navarro M, Mayor-Torroglosa S, Jiménez-López M, et al. A computerized analysis of the entire retinal ganglion cell population and its spatial distribution in adult rats. Vision Res. 2009;49:115-126.

82. Hughes S, Welsh L, Katti C, et al. Differential expression of melanopsin isoforms Opn4L and Opn $4 S$ during postnatal development of the mouse retina. PLoS One. 2012;7:e34531.

83. Langhammer CG, Previtera ML, Sweet ES, et al. Automated Sholl analysis of digitized neuronal morphology at multiple scales: whole cell Sholl analysis versus Sholl analysis of arbor subregions. Cytometry A. 2010;77:1160-1168.
84. Vidal-Sanz M, Salinas-Navarro M, Nadal-Nicolás FM, et al. Understanding glaucomatous damage: anatomical and functional data from ocular hypertensive rodent retinas. Prog Retin Eye Res. 2012;31:1-27.

85. Feigl B, Zele AJ. Melanopsin-expressing intrinsically photosensitive retinal ganglion cells in retinal disease. Optom Vis Sci. 2014;91:894-903.

86. Dauvilliers Y. Insomnia in patients with neurodegenerative conditions. Sleep Med. 2007;8:S27-S34.

87. Wullf K, Porcheret K, Cussans E, Foster RG. Sleep and circadian rhythm disturbances: multiple genes and multiple phenotypes. Curr Opin Genet Dev. 2009;19:237-246.

88. Schmoll C, Lascaratos G, Dhillon B, Skene D, Riha RL. The role of retinal regulation of sleep in health and disease. Sleep Med Rev. 2011;15:107-113.

89. Lax P, Esquiva G, Esteve-Rudd J, Otalora BB, Madrid JA, Cuenca N. Circadian dysfunction in a rotenone-induced parkinsonian rodent model. Chronobiol Int. 2012;29:147156.

90. Pfeffer M, Plenzig S, Gispert S, Wada K, Korf HW, Von Gall C. Disturbed sleep/wake rhythms and neuronal cell loss in lateral hypothalamus and retina of mice with a spontaneous deletion in the ubiquitin carboxyl-terminal hydrolase L1 gene. Neurobiol Aging. 2012;33:393-403.

91. Polo V, Garcia-Martin E, Bambo MP, et al. Reliability and validity of Cirrus and Spectralis optical coherence tomography for detecting retinal atrophy in Alzheimer's disease. Eye (Lond). 2014;28:680-690.

92. Garcia-Martin E, Satue M, Fuertes I, et al. Ability and reproducibility of Fourier-domain optical coherence tomography to detect retinal nerve fiber layer atrophy in Parkinson's disease. Ophthalmology. 2012;119:2161-2167.

93. Garcia-Martin ES, Rojas B, Ramirez AI, et al. Macular thickness as a potential biomarker of mild Alzheimer's disease. Ophthalmology. 2014;121:1149-1151.

94. Garcia-Martin E, Larrosa JM, Polo V, et al. Distribution of retinal layer atrophy in patients with Parkinson disease and association with disease severity and duration. Am J Ophthalmol. 2014;157:470-478.

95. Yu JG, Feng YF, Xiang Y, et al. Retinal nerve fiber layer thickness changes in Parkinson disease: a meta-analysis. PLoS One. 2014;9:e85718.

96. Jones BW, Marc RE. Retinal remodeling during retinal degeneration. Exp Eye Res. 2005;81:123-137.

97. Marc RE, Jones BW, Watt CB, Vazquez-Chona F, Vaughan DK, Organisciak DT. Extreme retinal remodeling triggered by light damage: implications for age related macular degeneration. Mol Vis. 2008; 14:782-806.

98. Wan J, Zheng H, Hu BY, et al. Acute photoreceptor degeneration down-regulates melanopsin expression in adult rat retina. Neurosci Lett. 2006;400:48-52.

99. Sakamoto K, Liu C, Tosini G. Classical photoreceptors regulate melanopsin mRNA levels in the rat retina. $J$ Neurosci. 2004;24:9693-9697.

100. Sánchez-Migallón MC, Nadal-Nicolás FM, Jiménez-López M, Sobrado-Calvo P, Vidal-Sanz M, Agudo-Barriuso M. Brain derived neurotrophic factor maintains Brn3a expression in axotomized rat retinal ganglion cells. Exp Eye Res. 2011;92: 260-267.

101. Machida S, Kondo M, Jamison JA, Khan NW, Kononen LT. $\mathrm{P} 23 \mathrm{H}$ rhodopsin transgenic rat: correlation of retinal function with histopathology. Invest Ophthalmol Vis Sci. 2000;41: 3200-3209.

102. Li S-Y, Yau S-Y, Chen B-Y, et al. Enhanced survival of melanopsin-expressing retinal ganglion cells after injury is associated with the PI3 K/Akt pathway. Cell Mol Neurobiol. 2008;28:1095-1107. 
103. Budhram-Mahadeo V, Morris $\mathrm{P}$, Ndisang $\mathrm{D}$, et al. The Brn-3a POU family transcription factor stimulates $\mathrm{p} 53$ gene expression in human and mouse tumour cells. Neurosci Lett. 2002; 334:1-4.

104. Faulkes DJ, Ensor E, Le Rouzic E, Latchman DS. Distinct domains of Brn-3a regulate apoptosis and neurite outgrowth in vivo. Neuroreport. 2004;15:1421-1425.

105. Hudson CD, Morris PJ, Latchman DS, Budhram-Mahadeo VS. Brn-3a transcription factor blocks p53-mediated activation of proapoptotic target genes Noxa and Bax in vitro and in vivo to determine cell fate. J Biol Chem. 2005;280:11851-11858.

106. Smith MD, Melton LA, Ensor EA, et al. Brn-3a activates the expression of $\mathrm{Bcl}-\mathrm{x}(\mathrm{L})$ and promotes neuronal survival in vivo as well as in vitro. Mol Cell Neurosci. 2001;17:460-470.

107. Smith MD, Ensor EA, Kinloch RA, Latchman DS. The POU domain transcription factor Brn-3a protects cortical neurons from apoptosis. Neuroreport. 2001;12:3183-3188.

108. Farooqui-Kabir SR, Budhram-Mahadeo V, Lewis H, et al. Regulation of Hsp27 expression and cell survival by the POU transcription factor Brn3a. Cell Death Differ. 2004;11:12421244.

109. Badea TC, Cahill H, Ecker J, Hattar S, Nathans J. Distinct roles of transcription factors brn $3 a$ and brn $3 b$ in controlling the development, morphology, and function of retinal ganglion cells. Neuron. 2009;61:852-864.

110. Jain V, Ravindran E, Dhingra NK. Differential expression of Brn3 transcription factors in intrinsically photosensitive retinal ganglion cells in mouse. J Comp Neurol. 2012;520: 742-755.

111. Lin B, Koizumi A, Tanaka N, Panda S, Masland RH. Restoration of visual function in retinal degeneration mice by ectopic expression of melanopsin. Proc Natl Acad Sci US A. 2008; 105:16009-16014.

112. Qiu F, Jiang H, Xiang M. A comprehensive negative regulatory program controlled by Brn3b to ensure ganglion cell specification from multipotential retinal precursors. J Neurosci. 2008;28:3392-3403. 